\title{
Investigating Factors Affecting Human Resource Productivity in Government Organizations
}

\author{
Navid Torabi ${ }^{1}$, Aboozar Jamshidvand ${ }^{2}$ \\ ${ }^{1}$ Department of Industrial Engineering, Science and Research Branch, Islamic Azad University, Tehran, Iran. \\ ${ }^{2}$ Faculty of Strategic Management, Supreme National Defense University, Tehran, Iran.
}

\begin{abstract}
This article examines the factors affecting human resource productivity in government organizations. Due to the endless innovations and changes that we are facing in the world, successful organizations have taken special measures to use all the intellectual and practical capacities of their employees. In today's world, attention to human resources as the axis of change and the basic element of any organization that operates under the influence of information and communication is more and more felt. Also, the idea of empowering, motivating and involving human resources is considered as one of the strategic and vital programs of managing. In this article, the factors affecting the increase of human resource productivity and the factors that reduce the productivity of human resource in government organizations have been fully studied.
\end{abstract}

KEYWORDS: Government Organizations, Human Resource, Human Resource Productivity, Motivation, Management, Productivity

\section{INTRODUCTION}

In today's world, the success or failure of an organization and especially, public organizations depends on how to attract and employ the human capital. Every organization is trying to promote its efficiency by properly using the available tools. It is necessary to promote the employees' skills and knowledge for public organizations' adjustment to global changes and transformation and their survival. There is significant evidence that productivity advancement in government organizations has not kept pace with the increases found in the private sector (Killefer \& Mendonca, 2006).

In 1993, the U.S. National Government passed the Public authority Execution and Results Act intended to require key plans and yearly execution reports from every single administrative office. Nonetheless, by 2008 , the demonstration and its prerequisites were generally being overlooked (Friel, 2008). Afterward, the Senate broadened the Public authority Execution and Results Act to require social event of information on key execution pointers. In any case, once more, government offices have not put the information gathered to any useful use (Brodsky, 2010). At last, in November 2011, "The administrative work the board chamber on Wednesday acknowledged proposals to further develop the public authority's exhibition the executives framework, endorsing for offices a guide that stresses better preparing for managers and more correspondence among representatives and their supervisors" (Lunney, 2011). In view of the outcomes introduced in this article, these latest drives might have the POTENTIAL for progress.

Organizational efficiency is considered one of the main foundations of success. Productivity is an inclusive concept whose promotion is a necessity for improvement of life quality, welfare, and humans' peace that are considered as basic goals of all countries and the politicians' and economists' concerns. One of the main goals of managers is to promote productivity. This goal can be achieved in different ways from changing a piece in the production procedure, changing the working shifts, changing the process of using the raw materials, and optimal use of the production process to changing the marketing and promotion strategies and employing efficient human force.

So, it can be claimed that human RESOURCE is the most valuable capital of every organization that tries to promote its efficiency and effectiveness by creating a fundamental transformation based on knowledge and insight.

\section{LITERATURE REVIEW}

Sara et al (2021) examined the effect of strategic planning, human resource management, and asset management on increasing the productivity of the rural economy. That research test was conducted using multiple linear regression with the OLS (Ordinary Least 


\title{
International Journal of Current Science Research and Review
}

\author{
ISSN: 2581-8341
}

\section{Volume 05 Issue 01 January 2022}

DOI: 10.47191/ijesrr/V5-i1-06, Impact Factor: 5.825

Square model. The results obtained were that strategic planning, human resource management, and asset management had a significant positive effect on increasing the productivity of the rural economy.

Subramony et al (2020) provided an empirical examination of the relationship between organizational investments directed toward the human resource (HR) function and a key performance outcome - labor productivity. They founded that HR function investments predicted labor productivity, and the proportion of HR staff occupying professional/technical roles moderated (enhanced) the HR function investment-labor productivity relationship.

Dey et al (2017) identified factors affecting human resource productivity in construction. They recommended that supervisors should be experienced, labours should be trained, financial incentives (bonus, award etc) should be given, communication should be improved, wastage should be minimized, clarity of technical information should be given to the workers and weekly progress report should be maintained.

Alkahtani (2013) surveyed the effects of emotional intelligence on organizational performance of higher education bodies of the Saudi Arabia and concluded that emotional intelligence has positive and significant effects on performance of the staff.

Jamshidi (2011) studied employees of the Bandar Abbas Customs Department to find a relationship between emotional intelligence and occupational performance. They concluded that there was a very positive and significant relationship between the two variables. They also found that there was a significant positive relationship between employees' performance and emotional intelligence.

Sahdat and Sajjad (2011) conducted a comprehensive study in Pakistan to evaluate and measure the effects of emotional intelligence on organizational performance and concluded that the higher the emotional intelligence, the higher the performance of the organization and vice versa.

\section{DEFINITION OF PRODUCTIVITY}

Productivity is a criterion that is the basis of judging the changes caused by human activities in the framework of a human-machine interactive structure.

Efficiency and effectiveness constitute two major components of productivity. Productivity leads to the evaluation of the return and results of the activities of an organization relative to its goals and resources.

Productivity= effectiveness (proper performance) + efficiency (proper fulfillment)

From another viewpoint, productivity originates from three major components: efficient technology, efficient labor force, and effective management.

Efficient technology refers to novel and improved methods, novel beliefs, innovation and invention, and modified and new materials. Efficient labor force refers to the provision of services in the due manner and working motivation. To achieve the efficiency of technology and labor force, this data should be effectively combined by the management to reach productivity. The following table 1 shows the comprehensive concept of productivity.

Table 1. Comprehensive concept of productivity

\section{What is it?}

An attitude to rationalize activities.

Prevention of canceled and useless work.

It means working smart.

- It is consumed correctly.

- $\quad$ The correct use of life for a better and more sublime life

- Proper productivity is a natural gift.

- Creating a pleasant and refreshing environment is possible.

- Matching quality and quantity and cost in competition.

- Being in your place in society.

- Cooperation and partnership.

\section{What is not?}

It is not just an economic and financial measure.

Not necessarily more work. It does not necessarily work harder.

- Not low consumption.

- $\quad$ Life is not for work.

- Not luxury.

- It is not just more production.

- $\quad$ It is not for personal gain

- it is not Exploitation

- It is not extreme strictness and pressure on people. 


\section{International Journal of Current Science Research and Review}

ISSN: 2581-8341

Volume 05 Issue 01 January 2022

DOI: 10.47191/ijcsrr/V5-i1-06, Impact Factor: 5.825

IJCSRR@ 2022

Www.ijesrr.org

\section{HUMAN RESOURCES}

Human resources is one of the valuable capital of every organization. On one hand, this factor is directly involved in production and service provision, and on the other hand, it is known as an agent coordinating the other factors involved in production. So, it has a dominant role among other factors.

Employees are valuable assets of every organization and achieving the organizational goals depends on proper management of these valuable resources. Labor force is an important and effective factor involved in productivity. A set of the factors and values governing an organization are effective in labor force efficiency. In past, it was thought that physical and material assets are major factors involved in the countries' progress, and the lack of these resources is a cause of underdevelopment in developing countries. So, these countries tried to achieve material capital and it led to their further dependency, and destruction of the economic, political, and cultural foundations. Nowadays, it has been found that sustainable development depends on the existence of powerful and efficient administrative institutions that have specialist human capital. Nowadays, human capital is emphasized for growth, and promotion of the quality of human force is a fundamental way of promoting productivity and accelerating economic growth. In other words, human force is the most important factor involved in productivity.

\section{The importance of human resources in organizations}

Humans play a major role as the fundamental basis of organizational development by attending group and organizational activities. Nowadays, organizations' growth and development depend on proper employment of human resources. Management theoreticians consider human as a complex phenomenon and powerful tools for organizational changes.

It seems that the main capital and the fundamental capital for the organizations' survival is paying increasing attention to human resources. Without regarding the needs of human resources, we cannot lead the organizational resources towards reaching the determined goals. Regarding the today's world that is referred to as the world of transformations, organizations are facing various challenges including the human resource challenges. In general, these challenges are caused by the changes in technology, structure, strategies, and organizational culture. Each of these changes can create new challenges in human resource management.

The organizations' active role in competition and technology, the emergence of new jobs, and the necessity of acquiring multiple skills for employees have made it unavoidable to empower them. Empowerment programs can promote the sense of self-efficacy and autonomy by assigning different responsibilities to individuals. As a result, organizational effectiveness and productivity will also grow. For this purpose, we need several infrastructures such as investment, motivated human force, and consistent attitudes. In addition to resolving the challenges of human resource management, it will promote the employees' loyalty and sense of belonging to the organizations that are manifested in their active participation, innovation, and creativity. The ultimate outcome will be the promotion of organizational productivity.

\section{THE FACTORS INVOLVED IN PRODUCTIVITY ENHANCEMENT}

Promotion of productivity is subject to a combination of different factors. So, we should first identify the cause of low productivity in an organization and then, propose improving plans including the changes in the way of motivating the employees and improving the working conditions, systems, instructions, methods, the technology, etc. Productivity can be considered one of the ways of promoting investment. In general, investment attraction can be realized in three ways:

Increasing the new human and physical capitals, and promoting the new capitals

Better use of the previous human and physical capitals and the new capitals

Using the previous capitals and attracting further investment

\section{Job justification}

Every employee should be aware of what is necessary to do, when and how to do that. To promote this knowledge, employees need to be aware of the long-term goals, priorities, and how to acquire them. They should know their goals and priorities.

\section{Performance feedback}

Performance feedback refers to informally making the individuals aware of their daily activities and formal periodical visits. An effective feedback procedure makes the employees aware of their working quality. 


\section{International Journal of Current Science Research and Review}

ISSN: 2581-8341

Volume 05 Issue 01 January 2022

DOI: 10.47191/ijesrr/V5-i1-06, Impact Factor: 5.825

IJCSRR@ 2022

WWw.ijesrr.org

\section{Organizational support}

Organizational support refers to a kind of support that is needed by the employees for their successful performance. Some of the aiding factors include sufficient budget, equipment, and necessary facilities that are proportional to the working process.

\section{Participation}

Participation refers to the individuals' mental and emotional involvement in group situations that make them motivated to help the organization to achieve its goals.

The following factors are some of the effective factors involved in human resource productivity:

- $\quad$ Continuous education of managers and employees

- $\quad$ Providing the opportunity for the managers and employees' innovation and creativity

- Establishing a performance-based salary system and an accurate system for punishment and encouragement

- $\quad$ Promotion of the employees' motivation for better working

- Job consciousness and social discipline

- $\quad$ Providing the employees with adequate authorities

- Transforming the systems and methods

- Strengthening the governance and dominance of organizational policies

- $\quad$ Proper action and behavior of the managers and leaders

- $\quad$ Providing the opportunity of professional advance

- Holding in-service training courses

- $\quad$ Giving specialized exams while employing the human force

- Involving the employees in decision making

- Clarity of the rules and the employees' tasks

- $\quad$ Planning professional tourism programs, professional enrichment, and professional development

\section{THE FACTORS DECREASING ORGANIZATIONAL PRODUCTIVITY}

In addition to the factors improving productivity, the factors impacting productivity should be also investigated to improve human resource productivity. Some of these factors include the following:

\section{Poor management}

Poor management is one of the main causes of low productivity in administrative organizations. The managers' unfamiliarity with planning techniques, organizing, human resource management, reward and punishment, motivation, control, and improper selection of managers at different levels, their frequent replacement, and lack of educational courses lead to poor management and decreased productivity.

Non-specialist human force: Knowledgeable and skilled employees will properly fulfill their tasks. So, to improve productivity, employees' specialty should be one of the main criteria for choosing them. It should be mentioned that employment and competent employees require establishing a human resource system that is based on meritocracy.

\section{Lack of proper employee assessment system}

Some of the goals of employee assessment systems include the ambiguity of the employees' weakness in performing their tasks and developing educational plans for improving them, motivating the employees by developing a rational reward and punishment system in the organization, creating a logical criterion in scoring the employees, and decreasing the complaints about biased opinions. So, employee assessment system should measure the human force performance as a criterion of modifying the inefficient procedures. A proper assessment system can promote the employees' motivation.

\section{Lack of the employees' motivation}

Promotion of organizational productivity is directly related to the employees' motivation for hardworking. Motivated employees can try to achieve the organizational goals, decrease the costs, and properly use the resources. Unfortunately, low motivation has been observed as a challenge for years. 


\section{International Journal of Current Science Research and Review}

ISSN: 2581-8341

Volume 05 Issue 01 January 2022

DOI: 10.47191/ijesrr/V5-i1-06, Impact Factor: 5.825

IJCSRR@ 2022

www.ijcsrr.org

\section{Individual utilitarianism}

If the members of an organization seek their personal goals and use the organizational resource to achieve their goals, organizational productivity that is the result of paying attention to organizational goals will be forgotten.

\section{The managers' busy program}

Some of the managers simultaneously take various administrative responsibilities. It prevents them from performing their tasks properly and on the due time. This situation will lead to the following problems:

A) It can impact the manager's performance. Humans do not have unlimited ability. So, the managers with multiple responsibilities may work deficiently due to the interference of their different tasks.

B) It makes the clients dissatisfied. The manager's failure to be permanently present due to the mass of tasks and responsibilities will stop the clients' affairs and dissatisfy them.

C) It will prevent the detection of potential talents and novel thoughts and methods.

\section{Procedures}

In public organizations, working procedures are traditional and mostly non-scientific and experimental. This condition causes various problems in administrative systems. These problems include the clients' confusion and the employees' tiredness.

Regarding the stated facts, the challenges of decreased human resource productivity in government organizations can be demonstrated in the figure 1 .

\begin{tabular}{|c|c|}
\hline \multicolumn{2}{|c|}{ Behavioral factors } \\
\hline $\begin{array}{l}\text { - Tribalism } \\
\text { - Lack of employee } \\
\text { participation } \\
\text { - Resistance to change } \\
\text { - Leave the job } \\
\text { - Bribery }\end{array}$ & $\begin{array}{l}\text { - Discrimination } \\
\text { - Without motivation } \\
\text { - Cultural barriers } \\
\text { - Mental biases } \\
\text { - Lack of knowledge } \\
\text { of staff needs }\end{array}$ \\
\hline
\end{tabular}

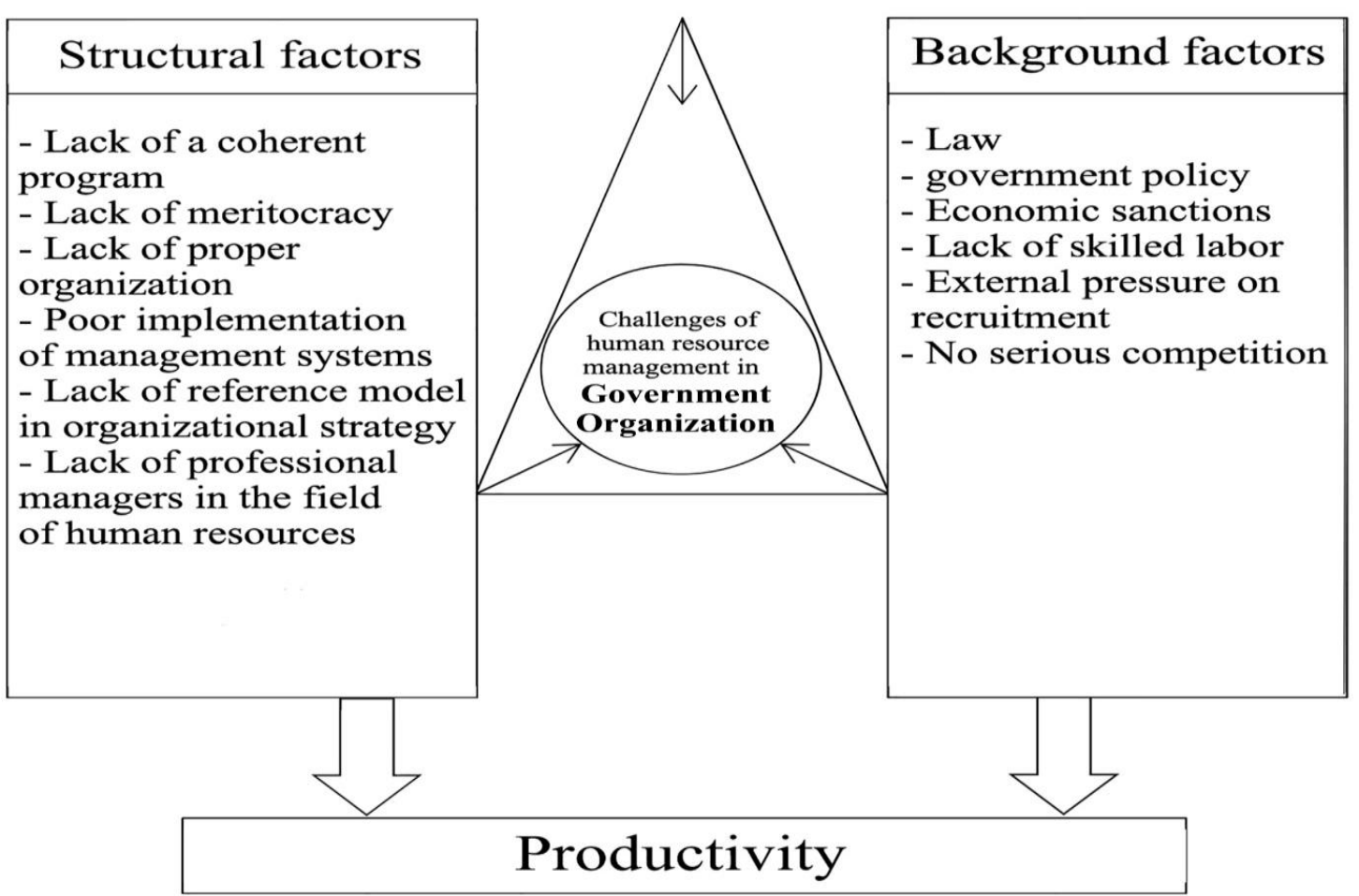

Fig 1. Challenges of decreased human resource productivity in government organizations 


\section{International Journal of Current Science Research and Review}

ISSN: 2581-8341

Volume 05 Issue 01 January 2022

DOI: 10.47191/ijcsrr/V5-i1-06, Impact Factor: 5.825

IJCSRR@ 2022

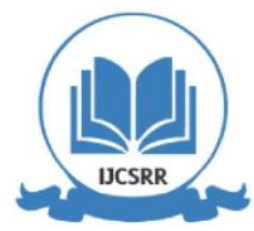

www.ijesrr.org

\section{CONCLUSION}

This paper examined factors affecting human resource productivity in government organizations. There are different opinions in determining the factors affecting productivity, and each scientist has identified factors as effective factors, and in short, factors such as continuous job training of managers and employees, promoting motivation among employees to work better and more, creating the ground Appropriate initiatives and creativity of managers and employees, establishing an appropriate payment system based on performance and establishing a system of punishment and encouragement, work conscience and social discipline, changes in systems and methods that play a critical role, and saving on effective productivity To be.

Factors such as poor management, unskilled manpower, busy managers, lack of motivation in employees, and inadequate evaluation system can be considered as cases of reduced manpower productivity in government organizations. For future research, the impact of various factors that affect productivity can be addressed on a case-by-case basis in various government departments, such as ministries, public service organizations, and so on.

\section{REFERENCES}

1. Alkahtani, A. (2013). Employee Emotional Intelligence and Employee Performance in the Higher Education Institutions in Saudi Arabia: A Proposed Theoretical Framework. International journal of business and social sciences, 4(9), 80-95.

2. Brodsky, R. (2010). Senators unveil bill to shape up agency performance. Government Executive. Available from www.govexec.com

3. Dey, S.S., Prabhu, S.M., Subramani, G.S. (2017). Identification and mitigation of factors affecting human resource productivity in construction. 8. 123-131.

4. Friel, B. (2008). Advice+dissent: Management matters. It ain't child's play. Government Executive. Available from www.govexec.com

5. Jamshidi, S., Bagherzadeh, E., Nikoo, H. (2011). Studying of relationship between emotional intelligence and employees performance: case study Bandar Abbas cus-toms in Iran. Shahed University.

6. Killefer, N., Mendonca, L. (2006, August 14). Unproductive Uncle Sam. Business Week, p. 86.

7. Lunney, K. (2011). Council moves forward on performance management plan. Government Executive. Retrieved from govexec.com

8. Sara, I.M., Saputra, K.A.K., Utama, I.W.K.J. (2021). The Effects of Strategic Planning, Human Resource and Asset Management on Economic Productivity: A Case Study in Indonesia. The Journal of Asian Finance, Economics and Business, 8(4), 381-389.

9. Sahdat, M., \& Sajjad, S. I. (2011). Emotional intelligence and organizational productivity: a conceptual study. World applied science journal, 15, 821-825.

10. Subramony, M. Guthrie, J.P., Dooney, J. (2021). Investing in HR? Human resource function investments and labor productivity in US organizations, The International Journal of Human Resource Management, 32(2), 307-330.

Cite this Article: Navid Torabi, Aboozar Jamshidvand (2022). Investigating Factors Affecting Human Resource Productivity in Government Organizations. International Journal of Current Science Research and Review, 5(1), 44-49 